\title{
Correction to: Combating an invisible enemy: the American military response to global pandemics
}

\author{
Lauren K. Dutton ${ }^{1,2^{*}}$, Peter C. Rhee ${ }^{1,3}$, Alexander Y. Shin ${ }^{1}$, Richard J. Ehrlichman ${ }^{4,5}$ and Richard J. Shemin ${ }^{6}$
}

\author{
Correction to: Mil Med Res 8, 8 (2021) \\ https://doi.org/10.1186/s40779-021-00299-3
}

In the original publication of this article [1], the "Disclaimer" section below is missing. The section of "Consent for Publication" should be replaced with "Not applicable." The original publication has been corrected.

Disclaimer:

The views expressed in this paper are those of the authors and do not reflect the official policy or position of the Departments of the Navy, Army, or Air Force, Department of Defense, or the U.S. Government.

Several of the authors are military service members and employees of the U.S. government. This work was prepared as part of their official duties. Title 17 U.S.C. 105 provides that "Copyright protection under this title is not available for any work of the United States Government." Title 17 U.S.C. 101 defines United States Government work as a work prepared by a military service member or employee of the United States Government as part of that person's official duties.
Author details

${ }^{1}$ Department of Orthopedic Surgery, Mayo Clinic, 200 1st Street SW, Rochester, MN 55905, USA. ${ }^{2}$ Navy Medicine Professional Development Center, Bethesda, MD 20889, USA. ${ }^{3}$ United States Air Force Reserve, the 60th Ops Squadron, Travis AFB, CA 94535, USA. ${ }^{4}$ Division of Plastic and Reconstructive Surgery, Massachusetts General Hospital, Boston, MA 02114, USA. ${ }^{5}$ Massachusetts National Guard, United States Army, Hanscom AFB, MA 01731, USA. ${ }^{6}$ Department of Surgery, Division of Cardiac Surgery,

Cardiovascular Center at UCLA, David Geffen School of Medicine at UCLA, Los Angeles, CA 90095, USA.

Published online: 04 February 2021

Reference

1. Dutton, et al. Mil Med Res. 2021;8:8 https://doi.org/10.1186/s40779-021-00299-3.

\footnotetext{
The original article can be found online at https://doi.org/10.1186/s40779021-00299-3.

* Correspondence: lauren.k.dutton@gmail.com

'Department of Orthopedic Surgery, Mayo Clinic, 200 1st Street SW, Rochester, MN 55905, USA

${ }^{2}$ Navy Medicine Professional Development Center, Bethesda, MD 20889, USA

Full list of author information is available at the end of the article
}

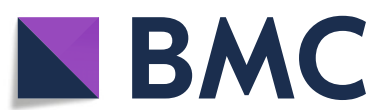

(c) The Author(s). 2021 Open Access This article is licensed under a Creative Commons Attribution 4.0 International License, which permits use, sharing, adaptation, distribution and reproduction in any medium or format, as long as you give appropriate credit to the original author(s) and the source, provide a link to the Creative Commons licence, and indicate if changes were made. The images or other third party material in this article are included in the article's Creative Commons licence, unless indicated otherwise in a credit line to the material. If material is not included in the article's Creative Commons licence and your intended use is not permitted by statutory regulation or exceeds the permitted use, you will need to obtain permission directly from the copyright holder. To view a copy of this licence, visit http://creativecommons.org/licenses/by/4.0/ The Creative Commons Public Domain Dedication waiver (http://creativecommons.org/publicdomain/zero/1.0/) applies to the data made available in this article, unless otherwise stated in a credit line to the data. 